\title{
Conjunctival excision or lamellar scleral autograft in 38 Mooren's ulcers from Sierra Leone
}

\author{
J. S. STILMA \\ From the Eye Hospital, Lunsar, Sierra Leone, West Africa
}

SUMMARY Ulcus rodens corneae (Mooren's ulcer) was studied in 30 patients with 38 corneal ulcers. Although the clinical picture resembled Mooren's description, the West African type of ulcus rodens is different in that it has a higher prevalence, a tendency towards perforation, is most frequent in the age group $20-40$ years, and is often associated with ankylostomiasis. Conjunctival excision with thermocoagulation gave some relief at the site of the ulcers, but recurrences at other places occurred in at least $52 \%$ of cases. Six eyes with a progressive iris prolapse and a flat anterior chamber were reconstructed with lamellar scleral autografts in the absence of donor corneas.

Ulcus rodens corneae was first described by A. C. Mooren in 1867. The original description was reviewed by Hoss ${ }^{1}$ in his biography of Mooren-a corneal ulcer with a peripheral groove and an undermined central edge, slowly progressive towards total corneal leucoma, some lid swelling and excessive pain and photophobia, vascular ingrowth from the conjunctiva, unilateral and bilateral, and resistant to therapy. Duke-Elder ${ }^{2}$ added to the description that the disease occurs in the elderly people and that there is no tendency to perforation. The prevalence of Mooren's ulcer seems to be low to judge by the number of cases published-about 100 in 100 years. In West Africa, however, over 100 cases have been described in the past 10 years. The geographical aspects of reports of Mooren's ulcer since 1965 (Duke-Elder and Kuriakose ${ }^{3}$ ) are summarised in Table 1.

The cause of Mooren's ulcer is unknown, although an immunological disorder was discovered by Schaap et al., ${ }^{31}$ later confirmed by others. ${ }^{42-40} \mathrm{~A}$ new classification was proposed by Wood and Kaufman. ${ }^{41}$ A possible relation between Mooren's ulcer and ankylostomiasis was mentioned by Kuriakose ${ }^{3}$ and Trojan. ${ }^{27}$ The treatment consisted in the past of a variety of methods, but is nowadays focused on excision of the adjacent conjunctiva with thermal or cryocoagulation.

The purpose of this report is to summarise the

Correspondence to Dr J. S. Stilma, Department of Ophthalmology, Free University, PO Box 7057, 1007 MB Amsterdam, The Netherlands. course of ulcus rodens corneae after conjunctival excision or lamellar scleral autografting. In a separate report on the immunological aspects (related to ankylostomiasis) patients with ulcus rodens will be compared with control patients.

\section{Material and methods}

The material consisted of new patients attending the Eye Clinic, Lunsar, Sierra Leone, from September 1980 to March 1982. The patients underwent visual acuity testing, tension, slit-lamp examination, ophthalmoscopy, and skin snip test for microfilariae of Onchocerca volvulus. The diagnosis Mooren's ulcer was made when there was a chronic, painful, peripheral deep corneal groove with an oedematous and undermined central edge, progressive around the periphery and towards the centre of the cornea. The undermining edge was tested with a cotton tip applicator. The limbal conjunctiva bordering the ulcer had to be swollen and injected. Pain and photophobia were normally present. Patients with rheumatic diseases were excluded.

Treatment started with excision of the conjunctiva and thermocoagulation of the ulcer edges. The conjunctiva was excised along the corneal groove till bare sclera was reached, but not exceeding $180^{\circ}$ in one session. A 3-4 mm strip of conjunctiva was removed. Any purulent conjunctivitis or hypopyon was treated first with antibiotics locally, subconjunctivally, or systematically. Iris prolapse with a flat or shallow anterior chamber was treated first by bed rest and 
Table 1 Geographical aspects of ulcus rodens corneae in recent reports

\begin{tabular}{|c|c|c|c|}
\hline Author & Country & Number & Remarks \\
\hline Adenis $^{4}$ & France & 1 & Scleral autoplasty \\
\hline Aviel $^{5}$ & Malawi & 5 & Cryocoagulation + peritomy \\
\hline Brown $^{6}$ & USA & 10 & Conjunctival excision \\
\hline Brown, Mondino ${ }^{7}$ & USA & 2 & Perforating keratoplasty \\
\hline $\mathrm{Cai}^{\mathrm{B}}$ & China & 56 & Cautery+excision \\
\hline Chihara et al.9 & Japan & 10 & Lamellar keratoplasty \\
\hline Christiansen et al. ${ }^{10}$ & USA & 2 & Cryocoagulation + peritomy \\
\hline Du Zian et al." & Japan & 1 & Lamellar keratoplasty \\
\hline El-Mofty ${ }^{12}$ & Egypt & 2 & Associated with pterygium \\
\hline Foster ${ }^{13}$ & USA & 2 & Use of methotrexate \\
\hline Gnandoss $^{14}$ & India & 10 & Conjunctival flap, cryocoagulation \\
\hline Joondeph et al. ${ }^{15}$ & USA & 2 & Hydrophilic contact lens \\
\hline Kabuni, Maertens $^{16}$ & Zaïre & 16 & Diathermy, iodine \\
\hline Kietzman $^{17}$ & Nigeria & 37 & Corneal debridement \\
\hline Lamba, Sood $^{18}$ & India & 6 & One patient of 12 years \\
\hline Lemos $^{19}$ & Brazil & 1 & \\
\hline Majekodumni ${ }^{20}$ & Nigeria & 5 & Conjunctival excision + helminthosis \\
\hline Matsuo $^{21}$ & Japan & 1 & Scanning microscopy \\
\hline Mondino $^{22}$ & USA & 2 & Herpes zoster association \\
\hline Pandey ${ }^{23}$ & India & - & Topical steroids \\
\hline Paton $^{24}$ & USA & 2 & Gunderson conjunctival flap \\
\hline $\mathrm{Pau}^{25}$ & W. Germany & 5 & Thermocoagulation \\
\hline Szusterowska ${ }^{26}$ & Poland & 1 & Tarsorrhaphy \\
\hline Trojan ${ }^{27}$ & Togo & 34 & Helminthiasis \\
\hline Urushima $^{28}$ & Japan & 1 & \\
\hline Wade, Diallo ${ }^{29}$ & Senegal & 27 & Resistant to therapy \\
\hline Young, Watson ${ }^{30}$ & Britain & 3 & Conjunctival flap, keratoplasty \\
\hline
\end{tabular}

antibiotics. If the iris prolapse increased and the anterior chamber did not reform, a conjunctival graft was considered. After some discouraging experiences with a conjunctival graft, and in view of the risk of losing the eye,${ }^{27}$ lamellar scleral autografts were used to restore the corneal defect and the anterior chamber when the iris prolapse was progressive. Sclera was chosen in the absence of donor cornea. The technique is described in a case history below.

\section{Results}

\section{GENERAL}

During 18 months' observation 30 patients presented with 38 Mooren's ulcers of the cornea. The disease was unilateral in 22 and bilateral in 8 patients. Nineteen were male and 11 female. The average age was 30 years, range 16 to 60 . Microfilariae of Onchocerca volvulus were found in the skin of 9 out of 30 patients, which is comparable with the average outpatient population in the Lunsar Eye Clinic. The extension of the ulcer along the circumference of the limbus was one quadrant in 7 eyes, 2 quadrants in 16 eyes, 3 quadrants in 12 eyes, and 4 quadrants in 3 eyes. At the end of the study the ulcer was in the same quadrant in 15 eyes, while in 17 eyes the ulcer had extended one or more quadrants and in 6 eyes it was unknown.

Stools were tested in 21 patients and contained: ankylostoma in 17 patients $(81 \%)$, Ascaris lumbricoides in 4 patients, trichiuris in 3 patients, and schistomiasis in 2 patients. No patient tested had negative stools, and 5 patients had 2 different parasites. Ankylostomiasis was treated with thiabendazol $25 \mathrm{mg} / \mathrm{kg}$ body weight for 2 days. Eosinophilia was tested in 14 patients and had an average value of 6.7 with an upper value of $15 \mathrm{~mm}^{3}$.

No operation was performed on 4 eyes with Mooren's ulcer, because the patient did not agree to one. In one case the ulcer did not progress in 3 months, in 2 eyes the ulcer was progressive, and one patient did not come back for follow-up.

Conjunctival excision and coagulation were performed in 23 out of 38 ulcers. Symptoms such as pain, irritation, and tearing showed improvement in 21. There was an acceleration of vascular ingrowth from the conjunctiva. No recurrences were detected in 9 out of 23 eyes, for which the average follow-up was 3 months. Recurrences occurred in 12 out of 23 eyes $(52 \%)$, which needed a second conjunctival excision at another place along the limbus. The average follow-up of the recurrences was 6 months.

Iris prolapse with a flat or shallow anterior chamber was present in 11 out of 38 eyes ( $29 \%$ ). In 6 eyes there was also hypopyon, which always cleared in a few days with gentamicin (drops and subconjunctival application) and oral antibiotics.

Bed rest restored the anterior chamber in 2 cases 


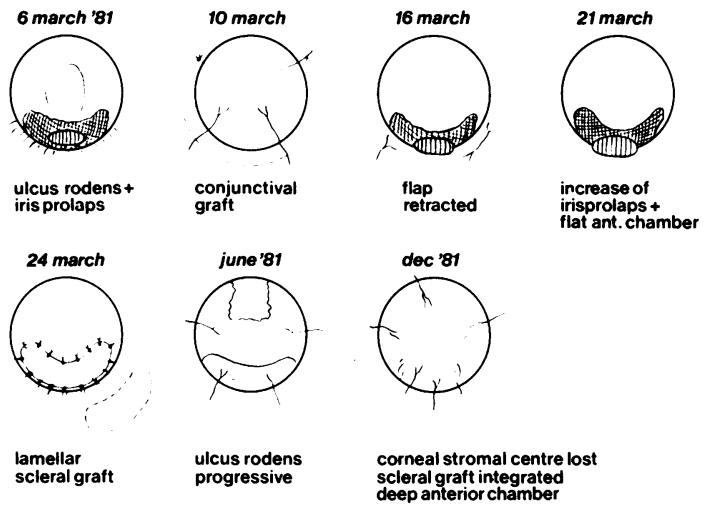

Fig. 1 Case history of patient 2, ulcus rodens corneae.

with a small prolapse. The management of eyes with Mooren's ulcer and iris prolapse not responding to bed rest changed during the course of the study: In a 24-year-old man a nonsurgical approach was followed with antibiotics, steroid tablets, a soft contact lens, and mild beta radiation, but the eye ended in panophthalmia and evisceration. A conjunctival flap was made in 2 patients but was successful in only one. The history of the unsuccessful conjunctival graft brought a turning point in the approach of iris prolapse in Mooren's ulcer and will therefore be described in detail.

\section{CASE HISTORY}

A girl aged 16 complained of pain and redness with tearing for 4 months (Fig. 1). The cornea had a deep groove in the 2 lower quadrants, with an undermined oedematous central edge. The anterior chamber was shallow, and there was a $2 \mathrm{~mm}$ iris prolapse at the 6 o'clock position. The limbal conjunctiva was swollen. On 10 March 1980 the limbal conjunctiva was excised and a lower conjunctival flap was prepared to cover two-thirds of the cornea. In 6 days the conjunctival flap was retracted completely and revealed a larger iris prolapse. Two weeks later the anterior chamber was flat and the iris prolapse had increased.

In the absence of donor cornea a free lamellar scleral autograft, half thickness, was obtained from the inferior temporal quadrant of the same eye. The iris prolapse was excised and the corneal defect closed with sclera. Although a continuous suture has the advantage over one knot, interrupted sutures $(9 \times 0$ or $10 \times 0$ monofilament nylon) were preferred because of the risk of a loose continuous suture if corneal destruction continued centrally. The anterior chamber was restored and remained so. However, the corneal ulcer was progressive to $360^{\circ}$ circumference despite repeated conjunctival excisions and coagulations.

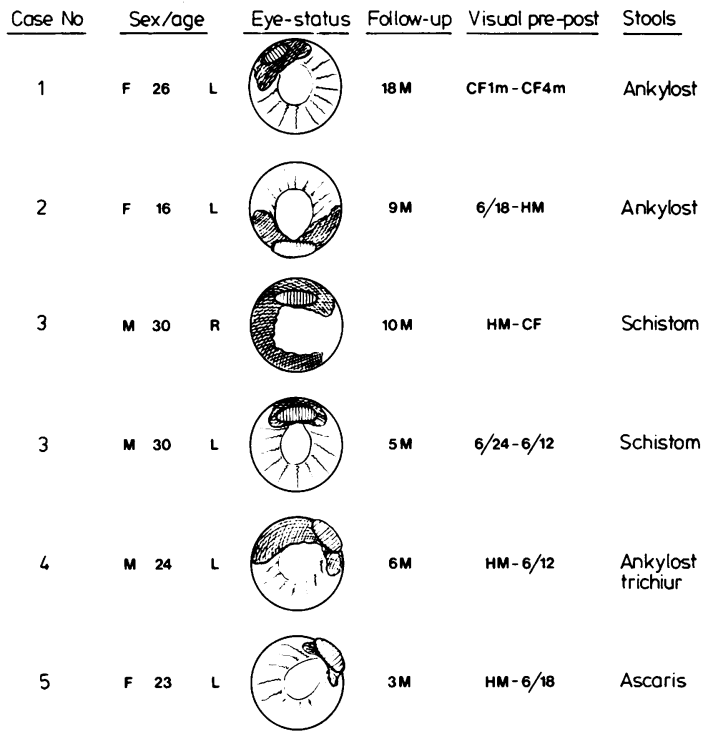

Fig. 2 Data for 6 eyes with perforated ulcus rodens corneae treated with scleral graft.

Nine months after the first visit the central corneal stroma was lost also. The remaining cornea was thin and vascularised; the intact scleral graft was clearing. The anterior chamber was still deep and the tension normal. A perforating keratoplasty could still be performed.

Lamellar scleral autografts were performed in 6 eyes of 5 patients, from which details are given in Fig. 2. All but one were in the upper quadrant, which is cosmetically more satisfactory in the first months. In no case was the eye lost, and in 5 quite useful vision was left. The wound closure was done in such a way that the anterior chamber could be restored with fluid at the end of the operation. On the side of the donor sclera no complications such as perforation or staphyloma were encountered.

Early Mooren's ulcer could be observed in 3 patients in whom the disease started during the treatment of the other eye. In the early stage the eye was rather quiet and showed only conjunctival swelling and redness at the limbus over $3 \times 1 \mathrm{~mm}$. In the cornea 2 or 3 greyish spots were seen in the stroma $1 \mathrm{~mm}$ from the limbus (diameter about $0.5 \mathrm{~mm}$ ). After 4-7 days the stromal spots melted together and simultaneously there was loss of corneal tissue leading to formation of a groove. In one eye the groove did not progress under local steroid therapy. In the second case it did increase under local steroids, but was arrested after conjunctival excision and coagulation. The third case with early Mooren's ulcer was progressive to $360^{\circ}$ despite repeated conjunctival excisions. 


\section{Discussion}

The ulcus rodens corneae seen in West Africa resembles Mooren's corneal ulcer so far as the corneal aspect and the difficulties in therapy are concerned. But in West Africa the prevalence is higher, perforation occurs in about $30 \%$, the main age group is $20-40$ years, and ankylostomiasis is frequent. However, ankylostomiasis is quite common in West Africa. ${ }^{42}$

Conjunctival excision and coagulation gave some pain relief and acceleration of vascular ingrowth from the conjunctiva, but recurrences on the other side or in the other eye occurred in at least $52 \%$. The progressive nature of the disease has led to loss of eyes and blindness. In the absence of donor corneas, lamellar scleral autograft proved to be useful in restoring the corneal defect and the anterior chamber in perforated eyes. Treatment of ankylostomiasis seems to be harmless and might be helpful in the prevention of further attacks.

The aetiology of West African ulcus rodens corneae needs clarification. Therefore a second study was undertaken to examine the immunological status of these patients in comparison with controls.

My thanks are due to the staffs of the Lunsar Eye Hospital (Dr E. Koeth) and Masanga Hospital (laboratory technician, P. Skrla).

\section{References}

1 Hoss J. Albert Mooren. Ein Augenarzt im 19. Jahrhundert. Düsseldorfer Arbeiten zur Geschichte der Medizin, 55. Düsseldorf: Triltsch, 1980.

2 Duke-Elder S. System of ophthalmology. London: Kimpton, 1980: 8 (2): 914

3 Kuriakose ET. Mooren's ulcer, etiology and treatment. Am J Ophthalmol 1963; 55: 1064-9.

4 Adenis JP, Bonnet Blanc JM, Queroy M, Rammaert B, Loubet A. Etude immunopathologique dans un cas d'ulcère de Mooren. Bull Soc Ophtalmol Fr 1977; 77: 719-21.

5 Aviel E. Combined cryoapplications and peritomy in Mooren's ulcer. Br J Ophthalmol 1972; 56: 48-51.

6 Brown SI. Mooren's ulcer: treatment by conjunctival excision. $\mathrm{Br}$ J Ophthalmol 1975; 59: 675-82.

7 Brown SI, Mondino BJ. Penetrating keratoplasty in Mooren's ulcer. Am J Ophthalmol 1980; 89: 255-8.

8 Cai SN. Clinical observation of 56 cases of Mooren's ulcer treated by excision-cautherization. Author's translation. Hung Hua Yen Ko Chin 1980; 16: 142-5.

9 Chihara E, Nishi R, Asayama K, Tsukahara I. Treatment of Mooren's ulcer by conjunctival excision. Ophthalmologica 1979; 170: 258-64.

10 Christiansen JM, Arentsen JJ. Surgical therapy of Mooren's ulcer: report of two cases successfully treated. Ann Ophthalmol 1975; 7: 1507-11.

11 Du Zian ZU, Jia Chen QI, Gong Xian Ming, Xu Hong Tao. Mooren's ulcer treated by lamellar keratoplasty. Author's translation. Nippon Ganka Gakkai Zasshi 1979; 83: 1855-60.

12 El-Mofty A. Bilateral simultaneous Mooren's ulcer with binasal and bitemporal pterygia. A possible aetiological and pathological correlation. Bull Ophthalmol Soc Egypt 1976; 69: 165-76.

13 Foster CS. Immunosuppressive therapy for external inflammatory disease. Ophthalmology 1980; 87: 140-50.
14 Gnandoss AS. An analysis of ten cases of Mooren's ulcer. Indian J Ophthalmol 1974; 22: 22-4.

15 Joondeph HC, McCarthy WLJR, Rabb M, Constantaras AA. Mooren's ulcer: two cases occurring after cataract extraction and treated with a hydrofylic lens. Ann Ophthalmol 1976; 8: 187-94.

16 Kabuni M, Maertens K. L'ulcus rodens ou l'ulcère de Mooren en république du Zaïre. Bull Soc Belge Ophthalmol 1975; 170: 612-20.

17 Kietzman B. Mooren's ulcer in Nigeria. Am J Ophthalmol 1968; 85: 788-91.

18 Lamba PA, Soo NN. L'ulcère de Mooren; une complication rare. Ann Oculist (Paris) 1969; 202: 331-6.

19 Lemos E. Considera cöones sobre a ulcere de Mooren. Rev Bras Oftalmol 1970; 29: 299-303.

20 Majekodunmi AA. Ecology of Mooren's ulcer in Nigeria. Doc Ophthalmol 1980; 49: 211-9.

21 Matsuo N, Okuda K, Matsuo H. Electron microscopy of Mooren's ulcer. Scanning electron microscopy observations. Folia Ophthalmol Jpn 1972; 23: 5-14.

22 Mondino BJ, Brown SI, Mondzelewski JP. Peripheral corneal ulcers with herpes zoster ophthalmicus. Am J Ophthalmol 1978; 86: 611-4.

23 Pandey R. Topical cortisone in the treatment of Mooren's ulcer. $J$ All India Ophthalmol Soc 1969; 17: 114.

24 Paton D, Milauskas AT. Gunderson-type thin conjunctival flaps for the cornea. Am Acad Ophthalmol Otolaryngol 1976; selected readings: $203-212$.

$25 \mathrm{Pau}$ H. Die Therapie des Ulcus rodens Mooren. Klin Monatsbl Augenheilkd 1978; 173: 62-8.

26 Szusterowska-Martinowa E. Case of Mooren's ulcer cured by tarsorrhaphy. Klin Oczna 1972; 42: 1415-7.

27 Trojan HJ. Ulcus rodens (Mooren)-Aspekte der Atiologie, des Verlauf und der Therapie. Klin Monatsbl Augenheilkd 1979; 174: 166-76.

28 Urushima CA, Kuroda N. Mooren's ulcer: a case report. Nippon Ganka Gakkai Zasshi 1979; 83: 72-6.

29 Wade A, Amoussou V, Diallo J. L'ulcère de Mooren au Senegal. African Med 1976; 707. After Trojan. ${ }^{27}$

30 Young RD, Watson PG. Light and electron microscopy of corneal melting syndrome (Mooren's Ulcer). Br J Ophthalmol 1982; 66: 341-56.

31 Schaap OL, Feltkamp TEW, Breebaart AC. Circulating antibodies to corneal tissues in a patient suffering from -Mooren's ulcer (ulcus rodens corneae). Clin Exp Immunol 1969; 5: 365-70.

32 Brown SI. Mooren's ulcer. Histopathology and ptroteolytic enzymes of adjacent conjunctiva. Br J Ophthalmol 1975; 59: $670-4$.

33 Brown SI, Mondino BJ, Rabin BS. Autoimmune phenomenon in Mooren's ulcer. Am J Ophthalmol 1976; 82: 835-40.

34 Brown SI. What is Mooren's ulcer? Trans Ophthalmol Soc UK 1978; 98: 390-2.

35 Eiferman RA, Hyndiuk RA. IgE in limbal conjunctiva in Mooren's ulcer. Can J Ophthalmol 1977; 12: 234-6.

36 Eiferman RA, Hyndiuk RA, Hensley GT. Limbal immunopathology of Mooren's ulcer. Ann Ophthalmol 1978; 10: 1203-6.

37 Mondino BJ, Brown SI, Rabin BS. Cellular immunity in Mooren's ulcer. Am J Ophthalmol 1978; 185: 788-91.

38 Foster CS, Kenyon KR, Greiner J, Greineder DK, Friedland B, Allensmith MR. The immunopathology of Mooren's ulcers. Am J Ophthalmol 1979; 88: 149-59.

39 Grayson M. The cornea. St Louis: Mosby, 1979.

40 Tabbara KF, Ostler HB. The role of the conjunctiva in peripheral corneal disease: the immunopathogenesis of Mooren's ulcer. VIth congress of European Society of Ophthalmology, Brighton, 1980. Royal Soc Med Intern Congress Symp Series No. 40.

41 Wood TO, Kaufman HE. Mooren's ulcer. Am J Ophthalmol 1971; 71 (suppl): 417-22.

42 Rodger FC. Onchocerciasis in Zaire. London: Pergamon Press, 1977. 